\title{
Constraints Faced by the Staff of Krishi Vigyan Kendras during their Job in Marathwada
}

\author{
V. B. Dhakne*, P. R. Deshmukh and S. G. Puri \\ Directorate of Extension Education, College of Agriculture, Golegaon, College of Community \\ Sciences, VNMKV, Parbhani, India \\ *Corresponding author
}

\section{A B S T R A C T}

K e y w o r d s
Constraints, Krishi
Vigyan Kendras
(KVKs),
Programme
Coordinators/
Senior Scientists
and Head, Subject
Matter Specialist

Keywords

Constraints , Krishi Vigyan Kendras Coordinators/ Senior Scientists and Head, Subject Matter Specialist

\section{Introduction}

Indian Council of Agricultural Research (ICAR) has developed a strong network of Krishi Vigyan Kendras (KVKs) in the country to disseminate agricultural technologies and innovations (Kumar et.al.2009). The first KVK was established in 1974 at Pondicherry and as on date of investigation total 716 KVKs were functioning in almost each and every district of India (Anonymous 2020). Maharashtra has $49 \mathrm{KVKs}$, whereas there are $12 \mathrm{KVKs}$ in Marathwada region which
Present study deals with the constraints faced by the staff of Krishi Vigyan Kendras (KVKs) during their job in Marathwada. Study was conducted in all $12 \mathrm{KVKs}$ functioning in Marathwada region of Maharashtra State, which includes 4 KVKs under the administrative control of VNMKV, Parbhani and remaining $8 \mathrm{KVKs}$ run by NGOs. Study was undertaken in the year 2020 with purposive sampling method. 70 Programme Coordinators/Senior Scientists and Heads and Subject Matter Specialists functioning in KVKs were selected for study. Data was collected by using the structured open ended schedule. Possible constraints which may hinder respondents working in KVKs were included in the schedule. Difficulty in disseminating complex technology $(51.42 \%)$ in technological constraints, too much report writing $(68.57 \%)$ in ministrative constraints, farmers rivalries in the villages $(55.71 \%)$ in socioonomic constraints in relation to farmers, untimely supply of budgets $(64.28 \%)$ in personal constraints were ranked first. 
and their transfer to the farmers in the larger interest of farmers and increase agricultural production. Main objectives of Krishi Vigyan Kendra are need based survey for identification of farmers needs and optimum use of available resources; conducting oncampus and off-campus long and short durational vocational trainings for the resource poor's; organization of front line demonstrations \& on farm trials on various aspects of agriculture and allied subjects and training rural women with respect of nutrition, health, sanitation, drudgery reduction and household enterprises.

Krishi Vigyan Kendras in India are playing an important role in transfer of agricultural technologies. In Marathwada KVKs has developed effective linkages with State Department of Agriculture (SDA) and Line Departments, ATMA, Small Scale Industries, Social Welfare Department, Maharashtra Centre for Entrepreneurship Development (MCED), Zilla Parishad, Panchyat Samities and NGO's. In addition to this help and guidance is always sought from sister institutes. The linkages fostered an interdisciplinary approach and communication among University/KVK Scientists, farmers and other groups as they work together.

However it is observed that many KVK Scientists/Subject Matter Specialists faces some constraints during their work. Hence the study was conducted with following specific objectives include to study the profiles of the respondents and to know the constraints faced by the respondents during their work.

\section{Materials and Methods}

The present study was undertaken with purposive sampling method in Marathwada region of Maharashtra state in year 2020. All $12 \mathrm{KVKs}$ functioning in Marathwada were selected for the study. Total 70 respondents were selected for the study. The selected respondents were Senior Scientist \& Heads/Programme Coordinator and Subject Matter Specialists working in KVKs who directly involved in organization of FLDs, OFTs, trainings and other extension programmes.

Data was collected by using the structured open ended interview schedule. Number of years of service at the time of investigation is considered as work experience. Attitude of the respondents was measured on five point continuum asking 10 statements expressing attitude of respondents towards job. Work environment was calculated on the basis of the perceived availability of physical facilities, staff, work load, target, communication and involvement in decision making for completing the task. Possible constraints which may hinder respondents working in KVKs viz. Technological constraints, Administrative Constraints, Socio-economic constraints in relation to farmers, Input/other materials constraints faced by the respondents and Personal constraints faced by the respondents were included in the schedule and responses given by the respondents were recorded. Frequency and percentage was calculated to classify the respondents.

\section{Results and Discussion}

\section{Profile of the respondents of KVKs}

The data with regards to profile of the respondents is presented in Table 1. The sample predominantly comprised $68.58 \%$ respondents of middle age (32 to 46 years), where as an equal percentage of respondents (15.71\%) were in young age (18 to 31 years) and old age (47 to 62 years) group.

Majority of the respondents $(82.86 \%)$ were male and 17.14 per cent were female. 
Regarding maternal status 90.00 per cent respondents were married and remaining 10.00 percent were unmarried. Large majority
(87.14 per cent) of the respondents were from farming background and remaining 12.86 per cent were from non-farming background.

Table. 1 The profile of the respondents $\mathrm{N}=70$

\begin{tabular}{|c|c|c|c|}
\hline Sr. No. & Profile and categories & Frequency & Per cent \\
\hline \multirow[t]{5}{*}{1.1} & Age (years) & & \\
\hline & Young (18 to 31$)$ & 11 & 15.71 \\
\hline & Middle (32 to 46$)$ & 48 & 68.58 \\
\hline & Old (47 and 62) & 11 & 15.71 \\
\hline & Mean -38.88 & SD -7.47 & \\
\hline \multirow[t]{3}{*}{1.2} & Gender & & \\
\hline & Male & 58 & 82.86 \\
\hline & Female & 12 & 17.14 \\
\hline \multirow[t]{3}{*}{1.3} & Marital Status & & \\
\hline & Married & 63 & 90.00 \\
\hline & Unmarried & 07 & 10.00 \\
\hline \multirow[t]{3}{*}{1.4} & Back ground & & \\
\hline & Farming & 61 & 87.14 \\
\hline & Non farming & 09 & 12.86 \\
\hline \multirow[t]{3}{*}{1.5} & Education & & \\
\hline & Post graduate with $\mathrm{Ph}$. D & 27 & 38.58 \\
\hline & Post graduate or any other & 43 & 61.42 \\
\hline \multirow[t]{5}{*}{1.6} & Work experience & & \\
\hline & Low (up to 4 year) & 14 & 20.00 \\
\hline & Medium ( 5 to 18 year) & 46 & 65.71 \\
\hline & High (19 years and above) & 10 & 14.29 \\
\hline & Mean -11.43 & SD - 7.35 & \\
\hline \multirow[t]{5}{*}{1.7} & Attitude & & \\
\hline & Unfavorable (Score up to 33) & 11 & 15.71 \\
\hline & Favorable ( Score 34 to 42 ) & 48 & 68.58 \\
\hline & More Favorable (score 43 and above) & 11 & 15.71 \\
\hline & Mean - 37.27 & SD -4.58 & \\
\hline \multirow[t]{5}{*}{1.8} & Work Environment & & \\
\hline & Low (below 19) & 14 & 20.00 \\
\hline & Medium (20 to 25$)$ & 49 & 70.00 \\
\hline & High ( above 25) & 07 & 10.00 \\
\hline & Mean - 22.18 & SD - 2.88 & \\
\hline
\end{tabular}


Table.2 Technological Constraints faced by the respondents of KVKs during their job

\begin{tabular}{|c|l|c|c|c|}
\hline S.N. & \multicolumn{1}{|c|}{ Technological constraints } & Number & (\%) & Rank \\
\hline $\mathbf{1}$ & Difficulty in disseminating complex technology & 36 & 51.42 & I \\
\hline $\mathbf{2}$ & Lack response from. & 35 & 50.00 & II \\
& & & & \\
\hline $\mathbf{3}$ & Lack of location specific technology. & 28 & 40.00 & III \\
\hline
\end{tabular}

Table.3 Administrative Constraints faced by the respondents of KVKs during their job

\begin{tabular}{|c|l|c|c|c|}
\hline S.N. & \multicolumn{1}{|c|}{ Administrative Constraints } & Number & $\mathbf{( \% )}$ & Rank \\
\hline 1 & Lack of support from other line department. & 22 & 31.42 & VIII \\
\hline 2 & Posts of supporting staff are less. & 40 & 57.14 & II \\
\hline 3 & Lack of incentives of excellent work. & 39 & 55.71 & III \\
\hline 4 & Lack of opportunities for updating knowledge. & 26 & 37.14 & V \\
\hline 5 & Lack of encouragement from superiors. & 25 & 35.71 & VI \\
\hline 6 & $\begin{array}{l}\text { Lack of cooperation from subordinates, office staff } \\
\text { and colleagues. }\end{array}$ & 13 & 18.57 & IX \\
\hline 7 & Shortage of transportation facilities. & 28 & 40.00 & IV \\
\hline 8 & Too much report writing. & 8 & 68.57 & I \\
\hline 9 & $\begin{array}{l}\text { Pressure from the local politician to fetch } \\
\text { more benefits from KVK schemes to own their } \\
\text { jurisdiction. }\end{array}$ & & & X \\
\hline 10 & Discrimination in rewards. & 23 & 32.85 & VII \\
\hline
\end{tabular}

Table.4 Socio-economic constraints in relation to farmers

\begin{tabular}{|c|l|c|c|c|}
\hline S.N. & Socio-economic constraints in relation to farmers. & No. & $(\%)$ & Rank \\
\hline 1 & Lack of decision making ability among farmers. & 36 & 51.42 & II \\
\hline 2 & Lack of interest among farmers. & 33 & 47.14 & III \\
\hline 3 & Lack of communication between the farmers. & 24 & 34.28 & IV \\
\hline 4 & $\begin{array}{l}\text { Lack of support from the farmers during FLDs and } \\
\text { OFTs. }\end{array}$ & 22 & 31.42 & V \\
\hline 5 & Rivalries in the villages. & 39 & 55.71 & I \\
\hline
\end{tabular}

Table.5 Input/other materials constraints faced by the respondents

\begin{tabular}{|c|l|c|c|c|}
\hline S.N. & $\begin{array}{l}\text { Input/other materials constraints faced by the } \\
\text { respondents. }\end{array}$ & No. & Rank \\
\hline 1 & Untimely supply of budgets. & 45 & 64.28 & I \\
\hline 2 & Insufficient supply of inputs. & 27 & 38.57 & IV \\
\hline 3 & Lack of regular supply of electricity. & 27 & 38.27 & V \\
\hline 4 & Insufficient infrastructure. & 41 & 58.57 & II \\
\hline 5 & Lack of internet connectivity. & 28 & 40.00 & III \\
\hline
\end{tabular}


Table.6 Personal constraints faced by the respondents

\begin{tabular}{|l|l|l|l|l|}
\hline S.N. & Personal constraints faced by the respondents. & No. & $(\%)$ & Rank \\
\hline 1 & Lack of freedom of expression. & 13 & 18.57 & IV \\
\hline 2 & Lack of cooperation from colleagues. & 8 & 11.42 & V \\
\hline 3 & Lack of time for frequent field visits. & 29 & 41.42 & II \\
\hline 4 & $\begin{array}{l}\text { Lack of freedom to disagree with decision taken by } \\
\text { superiors. }\end{array}$ & 18 & 25.71 & III \\
\hline 5 & Workload affecting other activities. & 50 & 71.42 & I \\
\hline
\end{tabular}

Regarding education 61.42 per cent of the respondents were post graduate and 38.58 per cent were post graduate with $\mathrm{Ph}$. $\mathrm{D}$. It was observed that majority (65.71 per cent) of the respondents were having medium level ( 5 to 18 years) work experience, while 20.00 per cent and 14.29 per cent respondents were having low level (up to 4 years) and high level (19 years and above) work experience, respectively.

As regards attitude significant number (68.58 per cent) of the respondents were having favorable attitude towards job, where as equal percentage (15.71 per cent) of the respondents were having more favorable attitude and unfavorable attitude towards job.

70.00 percent respondents perceived middle level of work environment followed by 20 percent and 10 percent respondents perceived low and high level of work environment respectively.

\section{Constraints faced by the staff of KVKs during their job}

Several constraints had been encountered by the respondents of KVKs during their job. The details responses from the respondents were enlisted in the Table 2.

\section{Technological constraints}

Results of Table 2 revealed that under technological constraints, majority of respondents $(51.42 \%)$ expressed difficulty in disseminating complex technology. They felt that highly sophisticated technologies were not only difficult to disseminate but are also not adopted by the farmers. Lack of response from the farmers to adopt technologies $(50.00 \%)$ ranked second fallowed by Lack of location specific technology $(40.00 \%)$. These findings are in conformity with the findings of Akshata Ramannanavar and Shobha Nagnur (2019) and Kumar and Kaur (2015).

\section{Administrative Constraints}

Data in the Table 3 depicts that under administrative constraints faced by the respondents, too much report writing ranked first (68.57\%). SMSs have to prepare monthly reports, quarterly reports, six monthly reports, annual reports, etc. Besides, these the activity reports like FLD and OFT reports, survey reports, impact analysis, stock reports are also required to be submitted from time to time. Due to too many report writing they are unable to do other activities like research paper and publications for farming community. These findings are in conformity with the findings of Akshata Ramannanavar and Shobha Nagnur (2019) and Kumar and Kaur (2015). Posts of supporting staff are less (57.14\%) ranked second. The findings are supported with the findings of Yadkikar (1999). Lack of incentives of excellent work $(55.71 \%)$, Shortage of transport facilities $(40.00 \%)$ and lack of opportunities for updating knowledge (37.14\%) were among the other constraints. 
Respondents also quoted that administrative constraints as lack of encouragement from superiors $(35.71 \%)$, discrimination in rewards $(32.85 \%)$, lack of support from other line department $(31.42 \%)$, lack of cooperation from subordinates, office staff and colleagues $(18.57 \%)$ and pressure from the local politician to fetch more benefits from KVK schemes to their own jurisdiction (11.42\%). Poonam and Surya Rathore (2017) also found that there is unwanted pressure from local politician to fetch more benefit.

\section{Socio-economic constraints in relation to farmers}

Results of Table 4 revealed that under Socioeconomic constraints in relation to farmers rivalries in the villages ranked first $(55.71 \%)$. lack of decision making ability among farmers $(51.42 \%)$ ranked second fallowed by lack of interest among farmers (47.14\%), lack of communication between the farmers $(34.28 \%)$ and lack of support from the farmers during FLDs and OFTs. (31.42\%) were the faced by the respondents,

\section{Input/other materials constraints faced by the respondents}

Data in the Table 5 depicts that under input/other materials constraints faced by the respondents, untimely supply of budgets ranked first (64.28\%).This finding coincides with finding of Poonam and Surya Rathore (2017). Insufficient infrastructure (58.57\%), lack of internet connectivity at KVK $(40.00 \%)$, insufficient supply of inputs $(38.57 \%)$ and lack of regular supply of electricity (38.27\%) were other constraints.

\section{Personal constraints faced by the respondents}

Regarding Personal constraints faced by the respondents results of Table 6 revealed that workload affecting other activities ranked first (71.42 \%) fallowed by lack of time for frequent field visits $(41.42 \%)$, lack of freedom to disagree with decision taken by superiors $(25.71 \%)$, lack of freedom of expression (18.57\%) and lack of cooperation from colleagues (11.42\%) were other constraints.

In conclusion the number of constraints affected the performance of the KVK staff. These constraints should be overcome for effective and efficient functioning KVKs. Difficulty in disseminating complex technology in technological constraints, too much report writing in administrative constraints, farmers rivalries in the villages in socio-economic constraints in relation to farmers, untimely supply of budgets in input/ other materials constraints, and workload affecting other activities in personal constraints were expressed by the majority of the respondents. Therefore, sensitization of KVK staff by organizing HRD programmes and providing technological backstopping, curtailment in workload and timely supply of budget is necessary for smooth functioning of KVKs.

\section{References}

Anonymous (2020) Retrieved from http://www.icar.org/content/krishivigyan-kendra.

Akshata Ramannanavar and Shobha Nagnur. 2019. Job Stress and Constraints of Subject Matter Specialists (SMSs) of Krishi Vigyan Kendras, Journal of Pharmacognosy and Photochemistry 2019:8(1):2317-2320.

Kumar M. Sethy S. and Gouri D.2009 Krishi Vigyan Kendra-Kisan Club linkage: an approach towards the agricultural prosperity. Indian Res. J.of Extension Education, 12: 48-52.

Kumar P. and Kaur P. Constraints faced by 
the Subject Matter Specialists of selected Krishi Vigyan Kendras of Northern India, J. Krishi Vigyan, 2015; $4(l): 10-17$.

Poonam and Surya Rathore. 2017. An analysis of constraints as perceived by KVK managers for effective functioning of Krishi Vigyan Kendras. Indian J. Agric. Res. 51(3), 2017: 277280.

Yadkikar D.R. (1991) Behavioral impact of KVK Maharashtra, An Analytical Study, Ph.D. Thesis, Marathwada Agricultural University, Parbhani.

\section{How to cite this article:}

Dhakne, V. B., P. R. Deshmukh and Puri, S. G. 2020. Constraints Faced by the Staff of Krishi Vigyan Kendras during their Job in Marathwada. Int.J.Curr.Microbiol.App.Sci. 9(11): 24992505. doi: https://doi.org/10.20546/ijcmas.2020.911.302 